\title{
Formation of Innovative Potential of Students
}

\author{
Tatyana Chernyshova \\ Chuvash State University \\ Cheboksary, Russia \\ tolivanova@yandex.ru \\ Dmitry Bobin \\ Chuvash State University \\ Cheboksary, Russia \\ dimbobin@mail.ru
}

\author{
Aleksandr Prokopev \\ Chuvash State University \\ Cheboksary, Russia \\ Loop711@mail.ru \\ Ekaterina Babeshkova \\ Chuvash State University \\ Cheboksary, Russia \\ babeshkova@inbox.ru
}

\begin{abstract}
This article deals with the problem of formation of innovative potential of a student's personality. Modern conditions of economic development require a new approach to the formation of employee competencies. Innovation has become not only the main criterion for increasing competitiveness, but also a necessary element for the survival of both the organization and the employee in the labor market. To meet these requirements, an employee must have a certain level of innovative potential. The formation of innovative potential of a student's personality as a future employee is the most important task of educational institutions. The study identified key personal qualities that form the innovative potential of a student's personality. The authors have developed a matrix of "creativityproductivity-trainability", which determines the possibility of realizing innovative potential in the practical conditions of the market environment
\end{abstract}

Keywords: an innovative potential, a student's personality, competencies, personal qualities

\section{INTRODUCTION}

In modern conditions, due to the rapid development of innovative processes in the world the requirements of employers to employees significantly increase. The employee must have a high degree of innovation potential for participation in various areas of innovative enterprise activity.

The formation of innovative potential of the future employee begins at the university. To study the individual's innovative potential, we conducted the survey of students of the FSEI HE (Federal State-Financed Educational Institution of Higher Education) Ulyanov Chuvash State University in the direction of bachelor degree in Organization Management.

\section{Literature ReVIEW AND Research Methods}

\section{A. Creativity and creative potential}

According to A. Maslow, "creativity" is a universal function of a person, which leads to all forms of selfactualization; the ability to create is innate, it is inherent in everyone and does not require special talents (Neubauer \& Martskvishvili, 2018).

The ability to create determines the creative potential of the individual. The definition "potential" (from lat. potential force) is interpreted as open opportunities in any respect. In the philosophical interpretation, "potential" is a source, opportunity, means, reserve which can be used by a person to solve a problem, achieve a certain goal. The references define the word "potential" as "latent qualities or abilities that may be developed and lead to future success or usefulness" ("Definition of Potential"). In relation to creativity, "potential" is ability to raise expression of individual creative abilities and creative performance through creativity training ("What Is Creative Potential").

During the XX century, creativity was considered from different positions (Euster, 2019). In early studies, the main emphasis was on creative thinking (Melnikas, 2019), and in later studies, attention was paid to the search for elements of creative personality, as well as motivation for the manifestation of creative behavior (Newman et al., 2018).

From an economic point of view, creativity is useful if its results can be commercialized (Frederiksen \& Knudsen, 2017). In this way, modern economic literature pays more attention to the concept of innovation as a commercial embodiment of creativity (Missikoff et al., 2015).

The relationship between creativity and innovation has been discussed for a long time (Sarooghi et al., 2015). The main difference is in the following: "Creativity and innovation at work are the process, outcomes, and products of attempts to 
as: academic performance, attendance, discipline, aptitude for learning.

Each indicator is a qualitative (for example, "like very much", "like", "do not like", etc.), or quantitative (for example, 5, 4, 3 times etc.) assessment. In order for marks to be comparable, they are " digitized", it means transfered into a universal scale from 0 to 10 points by methods of Qualimetry (Andreichicov et al., 2018). 10 points - corresponds to the best value of the indicator, and 0 points to the worst. For example, if the respondent's answer to the question "How often are you late for class?" is "Never", he is taken the maximum universal score " 10 ", he is taken " 0 "', if the answer is "Constantly", also intermediate values in the case of other answer options. In this way, all indicators become comparable and commensurable.

In addition, all indicators measured in the range from 0 to 1 are "standardized" and become "dimensionless" in order to compare the results obtained in the survey with other researches on this topic.

$$
z_{i j}^{(q)}=x_{i j}^{(q)} / x_{r e f \cdot j}^{(q)}
$$

$i$ - the number of the subject assessment, $i=1 . . n$;

$j$ - feature number for q-factor, $j=1 . . k_{q}, q=\{1,2,3\}$;

$k_{q}$ - the number of signs of the q-factor;

$z_{i j}^{(q)}-$ standardized assessment of the i-subject on the $\mathrm{j}$ sign of the q-factor;

$x_{i j}^{(q)}$ - assessment of the i-subject on the $\mathrm{j}$-sign of the qfactor on an absolute scale;

$x_{r e f . j}^{(q)}$ - reference value of $\mathrm{j}$-characteristic of $\mathrm{q}$-factor.

The expert group of five people was established to determine the "weight" of each indicator in the formation of the factors "Creativity", "Productivity" and "Trainability" and to assess the importance of the indicators of each factor by the Analytic hierarchy process (AHP) (Ishizaka, 2019). In this case, the indicators were compared in pairs by the degree of significance from 1 to 9 points.

\section{RESULTS}

The "Creativity" factor is primarily associated with the generation of new ideas. The factor "Creativity" is characterized by such indicators as: curiosity, activity, participation in project activities, generation of ideas.

The factor "Productivity" expresses the ability of the individual to finish the work. This factor is applicable to any activity, however, it is particularly important in innovation activity because of the high level of risk. This factor is characterized by such indicators as: commitment, selfdiscipline, vitality, exactingness.

The factor "Trainability" reflects the performance of the individual in the classes and the tendency to gain knowledge and experience. This factor is characterized by indicators such

\section{A. Weighting of indicators of innovation potential factors}

The obtained "weights" of indicators for each factor are presented in tables I-III.

TABLE I. WEIGHTS OF INDICATORS OF THE FACTOR «PRODUCTIVITY»

\begin{tabular}{|l|r|r|r|r|r|l|}
\hline \multicolumn{1}{|c|}{ Indicators } & E1 & E2 & E3 & E4 & E5 & Average \\
\hline Self-discipline & 0.20 & 0.25 & 0.26 & 0.17 & 0.10 & 0.20 \\
\hline Vitality & 0.13 & 0.15 & 0.06 & 0.11 & 0.06 & 0.10 \\
\hline Decisiveness & 0.56 & 0.45 & 0.46 & 0.59 & 0.68 & 0.55 \\
\hline Persistence & 0.11 & 0.15 & 0.22 & 0.13 & 0.16 & 0.15 \\
\hline
\end{tabular}




$$
P_{i}^{(q)}=\sum_{j=1}^{k_{q}} w_{j}^{(q)} \cdot z_{i j}^{(q)}, \quad i=1 . . n, j=1 . . k_{q}, q=\{1,2,3\}
$$
a significance level of 0.05 . Thus, expert assessments of the weights of the "Productivity" factor indicators can be considered consistent.

TABLE II. WEIGHTS OF INDICATORS OF THE FACTOR «CREATIVITY»

\begin{tabular}{|l|r|r|r|r|r|l|}
\hline \multicolumn{1}{|c|}{ Indicators } & E1 & E2 & E3 & E4 & E5 & Average \\
\hline Curiosity & 0.23 & 0.14 & 0.15 & 0.13 & 0.21 & 0.17 \\
\hline Project activity & 0.38 & 0.36 & 0.47 & 0.52 & 0.24 & 0.40 \\
\hline Ideas generation & 0.13 & 0.16 & 0.07 & 0.17 & 0.07 & 0.12 \\
\hline Activity & 0.26 & 0.34 & 0.31 & 0.18 & 0.48 & 0.31 \\
\hline
\end{tabular}

The concordance coefficient is 0.85 , which is important at a significance level of 0.05 . Thus, expert assessments of the weights of the "Creativity" factor indicators can be considered consistent.

TABLE III. WEIGHTS OF INDICATORS OF THE FACTOR «TRAINABILITY»

\begin{tabular}{|l|r|r|r|r|r|l|}
\hline \multicolumn{1}{|c|}{ Indicators } & E1 & E2 & E3 & E4 & E5 & Average \\
\hline Academic performance & 0.30 & 0.52 & 0.27 & 0.13 & 0.28 & 0.30 \\
\hline Attendance & 0.18 & 0.06 & 0.08 & 0.08 & 0.16 & 0.11 \\
\hline Discipline & 0.13 & 0.11 & 0.13 & 0.15 & 0.08 & 0.12 \\
\hline Aptitude for learning & 0.39 & 0.31 & 0.52 & 0.64 & 0.48 & 0.47 \\
\hline
\end{tabular}

The concordance coefficient is 0.74 , which is important at a significance level of 0.05 . Thus, expert assessments of the weights of the "Trainability" factor indicators can be considered consistent.

\section{B. Assessment of respondents' innovation potential factors}

Averaged estimates of innovative respondents' potential are presented in table IV.

TABLE IV. AVERAGE ASSESSMENTS OF INNOVATION POTENTIAL FACTORS

\begin{tabular}{|l|l|}
\hline \multicolumn{1}{|c|}{ Indicators } & \multicolumn{1}{c|}{ Average } \\
\hline Productivity & 0.715 \\
\hline Velf-discipline & 0.72 \\
\hline Decisiveness & 0.71 \\
\hline Persistence Creativity & 0.72 \\
\hline \multicolumn{1}{|c|}{ Trainability } & 0.70 \\
\hline Curiosity $\quad 0.514$ \\
\hline Project activity & 0.44 \\
\hline Ideas generation & 0.35 \\
\hline Activity & 0.42 \\
\hline & 0.68 \\
\hline Academic performance & 0.748 \\
\hline Attendance & 0.89 \\
\hline Discipline & 0.74 \\
\hline Aptitude for learning & 0.70 \\
\hline
\end{tabular}

Factors of students' innovative potential were evaluated with the formula:
$P_{i}^{(q)}-$ the value of the $\mathrm{q}$-factor for the $\mathrm{i}$ - evaluation subject;

$z_{i j}^{(q)}-$ standardized assessment of the i-subject on the $\mathrm{j}$ sign of the q-factor;

$w_{j}^{(q)}$ - the weight coefficient of the $\mathrm{j}$-characteristic of the $\mathrm{q}$-factor.

Estimates of the factors of innovative potential of the respondents are presented in figure 1.

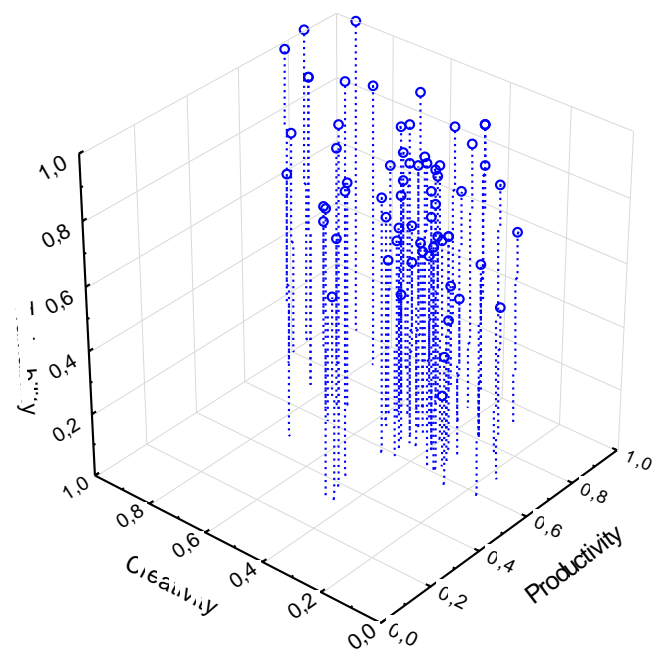

Fig. 1. Estimates of the factors of innovative potential of the students in the system "Productivity-Creativity-Trainability"

\section{Classification of respondents according to the factors of innovation potential}

The following classes are distinguished by the values of factors:

Class A (high level) - factor value is greater than 0.8;

Class B (intermediate level) - factor value is from 0.6 to 0.8 ;

Class C (low level) - factor value is less than 0.6.

The distribution of respondents by factor classes is presented in table $\mathrm{V}$.

TABLE V. DISTRIBUTION OF RESPONDENTS BY FACTOR CLASSES

\begin{tabular}{|c|c|c|c|c|c|c|c|c|c|c|}
\hline \multirow{4}{*}{ Productivity } & \multicolumn{9}{|c|}{ Creativity } & \multirow{4}{*}{ Sum } \\
\hline & $A$ & $A$ & $A$ & $B$ & B & $B$ & $C$ & $C$ & $C$ & \\
\hline & \multicolumn{9}{|c|}{ Trainability } & \\
\hline & $A$ & $B$ & $C$ & $A$ & $\boldsymbol{B}$ & $C$ & $A$ & $B$ & $C$ & \\
\hline A & 3 & 0 & 0 & 1 & 3 & 0 & 6 & 4 & 1 & 18 \\
\hline B & 3 & 1 & 0 & 2 & 3 & 0 & 8 & 14 & 9 & 40 \\
\hline $\mathrm{C}$ & 0 & 0 & 0 & 1 & 0 & 0 & 3 & 4 & 1 & 9 \\
\hline
\end{tabular}


have few opportunities for self-realization in the classes. The

\section{Integrated assessment of innovation potential}

Integral assessment of students' innovative potential was calculated in multiplicative form with the formula:

$$
I P=\sqrt[3]{P P \cdot C P \cdot T P}
$$

$I P$ - an integrated assessment of innovation potential;

$P P$ - a comprehensive assessment of the productivity factor;

$C P$ - a comprehensive assessment of the creativity factor;

$T P$ - a comprehensive assessment of the trainability factor.

The histogram of student distribution by the level of innovative potential is presented in figure 2 .

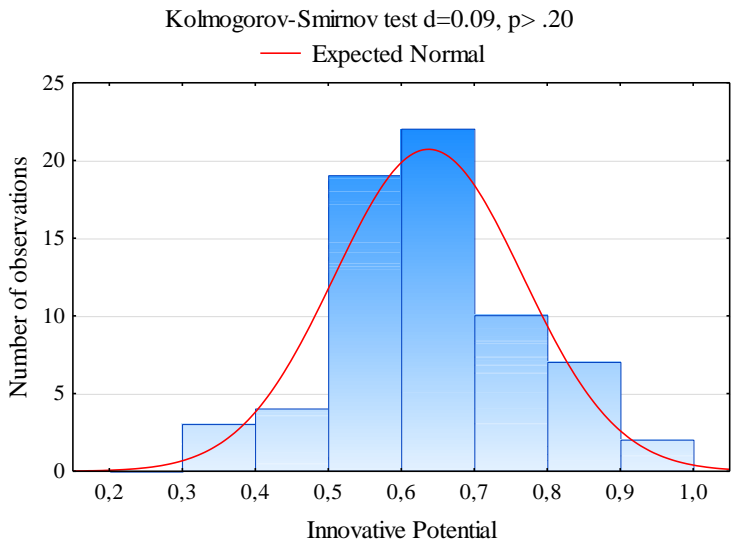

Fig. 2. Distribution of respondents assessments by the level of innovation potential

According to the Kolmogorov-Smirnov criterion (del Barrio et al., 2019), the obtained data have a normal distribution with a mathematical expectation of 0.638 and a standard deviation of 0.129 .

\section{DISCUSSION}

The survey involved 67 students of the Economic faculty in the direction of Organization Management. This survey was anonymous in order to increase the reliability of the obtained data. This decision was made, as in the practice of such studies affecting the learning process, students tried to overestimate the indicators, believing that the information can be available to to the administration of the University.

The survey of the students' innovative potential factors showed that they have higher indicators of the factors "Productivity" (0.715) and "Trainability" (0.748) reflected in table 4. This situation indicates that the students have developed qualities such as commitment, self-discipline, perseverance, vitality which are reflecting the productivity of activities. Also, students tend to be learnable, have high grades in disciplines and high attendance. However, the negative point is the fact that the value of the "Creativity" (0.514) factor is the lowest among students. The reason is a standard approach to the educational process in the University. Students choice of disciplines is limited, there is no practice of offering new disciplines by students. Students have low academic mobility.

The groups of respondents of interest are highlighted for a more detailed determination of students innovative potential levels.

TABLE VI. LEVELS OF INNOVATION POTENTIAL

\begin{tabular}{|c|c|c|c|c|}
\hline \multicolumn{3}{|c|}{$\begin{array}{c}\text { Factors of innovation } \\
\text { potential }\end{array}$} & \multirow{2}{*}{$\begin{array}{l}\text { Number } \\
\text { of } \\
\text { respond } \\
\text { ents }\end{array}$} & \multirow[b]{2}{*}{ Characteristic of the group } \\
\hline $\begin{array}{c}\text { Prod } \\
\text { uctivi } \\
\text { ty }\end{array}$ & $\begin{array}{l}\text { Creat } \\
\text { ivity }\end{array}$ & $\begin{array}{c}\text { Train } \\
\text { abilit } \\
y\end{array}$ & & \\
\hline A & A & A & 3 & $\begin{array}{l}\text { Level 1. Highest level of } \\
\text { individual's innovative } \\
\text { potential. The individual has a } \\
\text { high level of all innovative } \\
\text { potential factors }\end{array}$ \\
\hline A & A & B & 0 & \multirow{3}{*}{$\begin{array}{l}\text { Level 2. High level of } \\
\text { individual's } \\
\text { potential. The individual has a } \\
\text { high level on two factors of } \\
\text { innovative potential and an } \\
\text { average level on one factor of } \\
\text { innovative potential }\end{array}$} \\
\hline A & B & A & 1 & \\
\hline B & A & A & 3 & \\
\hline A & B & B & 3 & \multirow{3}{*}{$\begin{array}{l}\text { Level 3. Average level of } \\
\text { individual's innovation } \\
\text { potential. The individual has a } \\
\text { high level on one factor of } \\
\text { innovative potential and an } \\
\text { average level on two factors of } \\
\text { innovative potential }\end{array}$} \\
\hline B & A & B & 1 & \\
\hline B & B & A & 2 & \\
\hline B & B & B & 3 & $\begin{array}{l}\text { Level 4. Acceptable level of } \\
\text { individual's innovation } \\
\text { potential. The individual has an } \\
\text { average level for all innovative } \\
\text { potential factors }\end{array}$ \\
\hline
\end{tabular}

We will allocate the participants of the innovation project in accordance with the received groups as innovation activity involves teamwork.

Based on the obtained data, 3 respondents have an highest level of innovative potential (Level 1). This level indicates the readiness of the individual to implement innovative activities, in particular, as the head of the innovation project.

4 respondents have a high level of innovation potential (Level 2). This level indicates the ability of an individual to work in several areas of the innovation project, for example, student can engage in research and promotion of the project.

6 respondents have an average level of innovation potential (Level 3). This level indicates the possibility of working in one area of the innovation project.

3 respondents have an acceptable level of innovation potential (Level 4). This level is sufficient for an individual to work in a team and implement an innovative project as a performer.

Thus, there are $24 \%$ of students from all respondents with a sufficient level of innovative potential. The selected levels of students are of interest both for potential employers and for 
Entrepreneurial Leadership," Journal of Business Research, vol. 89, 2019, pp. 1-9, doi:10.1016/j.jbusres.2018.04.001.

the University. Universities are to monitor the dynamics of students' innovative potential development and promote the innovative potential development of bachelor undergraduate students with the creation of an information base for organizations.

One of the tasks of the University is to identify "bottlenecks" in the formation of students' innovative potential. The factor of "Productivity" can be increased through training, situational games, where the student assumes a high level of responsibility, as well as being in a situation of limited time for decision-making. Increasing the factor of "Creativity" may be due to the involvement of students in creative processes. We recommend business games with application of methods of brainstorming and synectics. In addition, it is necessary to introduce educational disciplines that contribute the development of students' creative abilities. It is possible to increase "Trainability" factor with the help of motivating students to acquire knowledge through the use of interactive learning methods, exchange of experience with other universities and non-trivial approaches to the organization of the educational process.

\section{REFERENCES}

[1] A.C. Neubauer, K. Martskvishvili, "Creativity and intelligence: A link to different levels of human needs hierarchy?," Heliyon, vol. 4(5), 2018, p. e00623, doi:10.1016/j.heliyon.2018.e00623.

[2] Definition of Potential,

Lexico, https://www.lexico.com/en?search_filter=dictionary.

[3] "What Is Creative Potential", IGI Global. Retrieved from https://www.igi-global.com/dictionary/enhancing-student-productivityusing-creativity/6159.

[4] J. Euster, "INNOVATIONS: Creativity, innovation and risk-taking," College \& Research Libraries News, vol. 48, 2019, pp. 405-406, doi:10.5860/crln.48.7.405.

[5] B. Melnikas, "Sustainable Social Development, Economic Growth And Technological Breakthroughs: Creativity And Creative Change," Creativity Studies, vol. 12(2), 2019, pp. 301-314, doi: 10.3846/cs.2019.10335.

[6] A. Newman, H.H. Tse, G. Schwarz, I. Nielsen, "The Effects of Employees Creative Self-Efficacy on Innovative Behavior: The Role of
[7] M.H. Frederiksen, M.P. Knudsen, "From Creative Ideas to Innovation Performance: The Role of Assessment Criteria," Creativity and Innovation Management, vol. 26(1), 2017, pp. 60-74, https://doi.org/10.1111/caim.12204.

[8] M. Missikoff, M. Canducci, N. Maiden, Enterprise innovation: from creativity to engineering, 2015, pp. 7-20, doi:10.1002/9781119145622.ch2.

[9] H. Sarooghi, D. Libaers, A. Burkemper, "Examining the Relationship between Creativity and Innovation: A Meta-Analysis of Organizational, Cultural, and Environmental Factors," Journal of Business Venturing, vol. 30(5), 2015, pp. 714-731., doi:10.1016/j.jbusvent.2014.12.003.

[10] N. Anderson, K. Potočnik, J. Zhou, "Innovation and Creativity in Organizations," Journal of Management, vol. 40(5), 2014, pp. 12971333, doi: 10.1177/0149206314527128.

[11] D.J. Hughes, A. Lee, A.W. Tian, A. Newman, A. Legood, "Leadership, Creativity, and Innovation: A Critical Review and Practical Recommendations," The Leadership Quarterly, vol. 29(5), 2018, pp. 549-569, doi:10.1016/j.leaqua.2018.03.001.

[12] J. Morgan, "What's the Difference Between Invention and Innovation?," Forbes, vol. 9, 2015.

[13] M.D. Mumford, E.M. Todd, Creativity and innovation in organizations. New York, 2019.

[14] E.E. Hagen, "How Economic Growth Begins: A Theory of Social Change," Journal of Social Issues, vol. 19, 1963, pp. 20-34, doi:10.1111/j.1540-4560.1963.tb00428.x.

[15] H. Venucia, "Embodiment - The Missing Link in Creative Innovation," International Journal of Innovation in Management, vol. 5(1), 2017, pp. 21-34, $\quad$ Retrieved from https://www.academia.edu/34379735/Embodiment_The_Missing_Link_ in_Creative_Innovation?source=swp_share.

[16] U. Barańczuk, "The Five Factor Model of Personality and Alexithymia: A Meta-Analysis", Journal of Research in Personality, vol. 78, 2019, pp. 227-248, doi:10.1016/j.jrp.2018.12.005.

[17] I. Ali, "Personality traits, individual innovativeness and satisfaction with life," Journal of Innovation \& Knowledge, vol. 4(1), 2019, pp. 38-46, doi:10.1016/j.jik.2017.11.002.

[18] A. Andreichicov, Y. Firsov, A. Zudinov, E. Tabunov, O. Andreichicova, New Paradigms of Decision-Making and Qualimetry, 2018, doi:199203. 10.1109/ITMQIS.2018.8525105.

[19] A. Ishizaka, Analytic Hierarchy Process and Its Extensions, 2019, doi:10.1007/978-3-030-11482-4_2.

[20] E.D. Barrio, H. Inouzhe, C. Matrán, On approximate validation of models: a Kolmogorov-Smirnov-based approach, 2019, doi:10.1007/s11749-019-00691-1. 